soya beans from Nigeria and tobacco from Cyprus. Of the 824 inquiries, the report mentions particularly those relating to lemon juice and peel, papain, jute and jute substitutes, cellulose for wood and rayon pulp and short-length piassava from Sierra Leone.

The Intelligence Section of the Mineral Resources Department dealt with 1,048 inquiries, and among these vermiculite continued to figure, while other inquiries related to supplies of beryl, zinc deposits in Burma, Empire resources of sillimanite minerals, Indian and Australian pyrophyllite, barytes for oilwell drilling muds, and clays for bases in soap substitutes. Staff limitations have prevented resumption of the preparation of revised editions of the series of mineral monographs, but the mineral resources section of the quarterly Bulletin of the Institute has continued, and results of the investigations on samples of coal from Tanganyika were published as an appendix to an article in the Bulletin on the geology of the Namwele-Mkomolo Coalfield by R. B. McConnell. Among the investigations carried out during the year may be recorded those on bleaching earth from Cyprus, lignite from Sierra Leone, manganese ore from Dominica, and clays, coral, volcanic materials and sands from St. Vincent as possible building materials.

The Rubber Department gave its chief attention during the year to a continued study of the resilience of rubber, and improvement in resilience of Hevea rubber by thorough purification previously reported has been confirmed. The vulcanizing and mechanical properties of the highly purified rubber have been studied in some detail, as well as the effect of treating the latex with substances likely to affect molecular cohesions and linkages. Attempts have also been made to determine the association of phosphorus with the rubber particles in preserved latex.

The report also includes an account of the educational work of the Institute, both its publications and exhibitions, the Central Film Library, the Empire Lantern Slide and the Film Strip Library and the general library, to which more than 5,700 books, official reports and pamphlets were added in 1947, in addition to the 800 periodicals normally received.

\section{THE FISHERIES SCHOOL AT CRONULLA, NEW SOUTH WALES}

$\mathrm{O}^{\mathrm{n}}$ NE of the most interesting and informative technical publications issued in connexion with any fishing industry is the Australian Fisheries Newsletter published by the Commonwealth Fisheries Office. This first-rate monthly never fails to provide a wealth of accurate and helpful information covering all aspects of Australian fishing activities together with a useful leavening of articles and news items dealing with the more general aspects of marine biology and its bearing on fisheries problems in all parts of the world. Of particular interest has been a series of articles* on the foundation and development of a fisheries training school on a site adjoining the Marine Biological Laboratory of the Australian Council of Scientific and Industrial Research in New South Wales.

* Fisheries Neusletter, 5, No. 2, 3 (April 1946); 6, No. 1, 3 (Feb. 1947); 6, No. 2, 8 (April 1947); 6, No. 5, 3 (Oct. 1947). Published by the Commonwealth Fisheries Office, Dept. of Commerce and Agriculture, at the Publicity Press (1938) Pty., Ltd., 71-75 Regent Street, Sydney.
The Australian fishing industry at the present time employs some ten thousand persons in actual fishing. No accurate figures are available concerning the number of persons engaged in ancillary occupations. Very rapid developments were made during the Second World War, and since the conclusion of hostilities there has been a heavy influx of new personnel. Many of those have come from families already in the industry; but there is also a steady recruitment of ex-Service men without previous experience of any branch of fishing activity. In order to ensure that those men shall have the best possible chance of making good in their new occupation a Commonwealth Fisheries School has been established at Cronulla, New South Wales, well equipped and adequately staffed for the work it sets out to do.

A technical supervisor is responsible for technical training. $\mathrm{He}_{\theta}$ is assisted by an assistant technical supervisor, and the masters and crews of the school's instructional vessels, which comprise a 75-ft. diesel trawler, a 66-ft. Danish seiner, a 25-ft. inshore motor fishing vessel and several smaller boats.

The more theoretical side of the instruction is given by officers of the Fisheries Division and the Division of Food Preservation and Transport of the Council of Scientific and Industrial Research, the staff of the Sydney Technical College, and members of the Commonwealth Fisheries Office.

The trainees reside on the premises, so a camp superintendent is in charge of the school buildings, assisted by a quartermaster, cooks and camp attendants. There are thirty bedrooms, each accommodating two persons, and a 'loughboy' for storing clothes and other personal gear. Adequate bathing facilities and a laundry are also available. The large messroom can accommodate seventy persons, and the catering staff, operating an all-electric kitchen, provide a good service of both hot and cold meals.

Approved applicants accepted for full-time training pay no fees for the course. Where necessary, an allowance is made for books, tools and other essentials, and, in addition, a living allowance of $£ 35 s$. a week is paid to those without dependants. To a trainee with dependants an additional sum up to a maximum of $\mathfrak{i 2}$ a week may be paid, according to the number of dependants and their degree of dependency.

The course at Cronulla was originally planned to extend over four months, after which the trainees were required to go into subsidized employment in the fishing industry in order to obtain further intimate experience of practical work. Difficulty has been experienced, however, in placing the trainees in subsidized jobs because fishing in Australia is mostly operated by one-man boat-owners, by crews who are joint owners of their own boat, and by owners with crews on a share basis. It has therefore been decided that the training course shall be extended from four months to thirty weeks and that the period of subsidized employment be abolished. It is thought that the longer course will provide sufficient practical experience in the fishery school's own vessels to enable its students to stand at once on their own feet in the fishing industry. To assist in achieving this objective some of the theoretical instruction given during the first course will be reduced and more time given to practical work both at sea and on shore. For the first twenty weeks all trainees will take the general fisheries syllabus, after which they will specialize in that branch of the industry which they intend to enter. 
It is felt in some quarters that a school of fishing should be established in Great Britain, particularly for the training of fishery officers and others who will be going out to British Colonies under the Colonial Development Scheme. It is doubtful whether there would be enough trainees derived from this source to support a satisfactory school on a permanent basis. But the British fishing industry also would benefit if the recruits to its ranks could have a period of training in a well-planned and wisely conducted school of fisheries such as that at Cronulla. Fishing in Britain and other European countries has long ceased to be run on primitive 'rule-of-thumb' lines, and there seems at present to be a decided danger that British fishermen may be outstripped by Continental rivals who give more attention to the proper study of fishing in all its aspects.

G. A. Steven

\section{BOTTOM DEPOSITS OF LAKE WINDERMERE IN RELATION TO THE QUATERNARY HISTORY OF THE BRITISH ISLES}

\footnotetext{
$\mathrm{T}$
}

HE importance of the bottom deposits of Lake

Windermere as a source of information concerning the post-glacial history of north-westerm England has already been indicated by the stratigraphy and diatom sequence established by Winifred Pennington (Mrs. T. G. Tutin) (New Phytol., 42, 1 ; 1943). These deep-water deposits (brought within reach by the unique qualities of the Jenkin coresampler) have been used again by the same worker to extend our knowledge into the late-glacial period (Phil. Trans. Roy. Soc., B, 233, 137 ; 1947). Waterlaid, laminated clays are found above and below a layer of grey detritus silt which contains remains indicating that it was laid down during a cooltemperate phase. This is tentatively correlated with the Allerød oscillation established in north-westerm Europe and Ireland.

Analysis of the post-glacial layers (utilizing both pollen and macroscopical plant remains) reveals a fairly close correlation with events in East Anglia, except in the later stages where a Salix maximum occurs in Zone IV and Betula assumes, in Zone V and early Zone VI, the dominance characteristic of profiles from the west of Britain. Tilia does not appear until Zone VII, and Fagus and Carpinus are completely absent. Pinus, which appears to be consistently over-represented in the deep-water deposits, falls off very rapidly at the transition between Zones VIc and VII, but always reappears at a characteristic position near the surface, where the brown and indurated clay gives way to soft, black, rather unconsolidated gyttja. This reappearance may be due to planting (a rise in the importance of grass pollen in deposits laid down 2,000-2,500 years ago having already suggested the beginning of clearance of the primeval forests).

Samples from beneath shallow water provided the clearest pictures of the late-glacial and early postglacial changes, but deposition appears to have ceased (due to turbulence) when the mud has approached to within about three metres of the water-surface. The lesser clarity of the early stages of deep-water samples appears to be due to a very slow deposition here.
Possible correlations of dating with geological reports for north-western England, Ireland and Scandinavia are clearly shown in tabular form, and it is concluded that the lower laminated clay is contemporaneous with the Scottish re-advance, the Carlingford re-advance in Ireland and the Lower Dryas clay in Denmark, and its end is placed at about 10,000 B.c. The commencement of the deposition of the upper laminated clay is placed at 8,300 B.c., and its continuation for some four to five hundred years (estimated by counting the varves) is believed to be the result of a valley glaciation in the Lake District. This is correlated with the Antrim coast re-advance and valley glaciation in the Wicklow Mountains, the Upper Dryas clay of Denmark and the formation of the great Fenno-Scandian moraines. In the post-glacial period, a dating between 6,300 and 6,000 B.c. for the Boreal-Atlantic transition also agrees with Scandinavian results.

A brief correlation with the previous work is made and the greater detail revealed by pollen-analysis is demonstrated, while the same technique is also made to shed further light on the stratigraphical results previously obtained.

H. G. BAKER

\section{THE NORWEGIAN POLAR INSTITUTE}

$O^{N}$ March 1, the Norwegian Polar Institute (Norsk Polarinstitutt) was established in Oslo in order to continue and expand the activity of Norges Svalbard- og Ishavs-undersøkelser. The latter office was founded in 1928, when it took over the work which since 1909 had been carried out by Government-supported expeditions to Svalbard. Norges Svalbard- og Ishavs-undersøkelser has been engaged in the preparation of topographic maps and hydrographic charts of the Svalbard region and in geological investigation on Svalbard. It has provided facilities for numerous scientific workers to visit Svalbard and Eastern Greenland, and has carried out a large amount of practical work such as the estah. lishment of aids for navigation and maintenance of weather stations.

Besides continuing this work, the Polar Institute will broaden the scope of the scientific activity, partly by adding specialists of its own permanent staff, and partly by securing the collaboration of specialists who are connected with university institutions in Oslo and Bergen and other scientific organisations. The sphere of interest will be expanded to include the regions of the Antarctic over which Norway claims sovereignty. It is hoped that the Polar Institute will be able to undertake, sponsor or stimulate geological and palæontological research, glaciological and meteorological studies as well as work in the fields of zoology and botany. The publications of Norges Svalbard. og Ishavs-undersøkelser (Skrifter and Meddelelser) will be continued from the Polar Institute without any break in the numbering.

The Polar Institute will not absorb organisations which are primarily engaged in scientific work in the polar regions, such as the Aurora Observatory at Tromsö or the Government Institute of Whaling Research in Oslo; wherever desirable, it will collaborate with these organisations.

The Polar Institute comes under the Department of Industry of the Norwegian Government, but Dr. H. U. Sverdrup, who has been appointed director, 